\title{
Incidence of Malignancy in the Future?
}

Sir,

The incidence of communicable disease is started decreasing in most of the developing and developed countries. Now, it is era for noncommunicable disease such as diabetes, hypertension, obesity, and malignancy. The development of malignancy is a multifactorial. ${ }^{[1]}$ It includes environmental factors, toxins, microbiological agents, and genetic mutation. As per Charles Darwin statement, any living tissue to maintain its sustainability, it has to undergo several modifications. We know our human race also acquired several anatomical and genetic changes before reaching current era.
Now, there are increased incidences of malignancy because of environmental factors or microbiological factors. These increased incidences may be due to high exposure of environmental toxins or detection of malignancy by available medical gadgets. However, in the future, there are changes that might happen in our own genome to maintain our human rare. The best example for this is the development of genetic mutation or alteration of proteins by microorganism against particular antibiotics. Before three decades, penicillin is a very good antibiotic with broad spectrum action to all organisms. Soon later, there are developmental modifications in the microorganism for antibiotics susceptibility. Now, we can see beta-lactamase-producing 
bacteria, methicillin-resistant bacteria, and extended methicillin-resistant Staphylococcus aureus. ${ }^{[2]}$

Above said was an example for genetic modification for sustaining life. Similar effect might happen in human genome also, that make our genome resistant against environmental toxins. Now, we see a lot of patients with malignancy at younger age group than older age group. It may be due to environmental factors or early detection. ${ }^{[3]}$ We know that in our genome, we have p53 which is called guardian of genome because it acts as a filter against the development of cancer cells. Similar to p53 genes, we have numerous genes which control the proliferation of cells. ${ }^{[4]}$ In due course, our genome also undergoes modification to evade genetic modification made by environmental factors. This can happen by several ways such as the development of alternative pathways, resistant to environment factors. In the future, our somatic cells will undergo genetic modification thereby it decreases the incidence of malignancy. However, it may not be permanent because modified gene can be susceptible to other factors which may not be risk factors now. It is important because we can anticipate less incidence of current malignancy and development of new malignancy. Second, currently available chemotherapeutic agent may not be efficient against new malignancy. For example, when we identified imatinib for chronic myeloid leukemia, it was very effective against cancer cells. But, very soon, there is the development of malignant cells which were resistant to imatinib and susceptible to sunitinib ${ }^{[5]}$ In the future, there will be reports of sunitinib-resistant malignancy.

To conclude, genetic alterations are always mandatory to sustain the life of living organism. If that organism fails to undergo modification, that genome will be erased from life. Similar effect might happen in human genome also, against cancer cells by means of genetic alteration to tackle environmental stimuli. Hence, we need to develop new chemotherapeutic agent or genetic alteration that might tackle future incidence of malignancy.

Financial support and sponsorship

Nil.

\section{Conflicts of interest}

There are no conflicts of interest.
Jayabal Pandiaraja

Department of General Surgery, SRM Medical College, Kancheepuram, Tamil Nadu, India

Address for correspondence:

Dr. Jayabal Pandiaraja,

26/1, Kaveri Street, Rajaji Nagar, Villivakkam, Chennai - 600 049,

Tamil Nadu, India.

E-mail:dr.pandiaraja@gmail.com

\section{References}

1. Misganaw A, Mariam DH, Ali A, Araya T. Epidemiology of major non-communicable diseases in Ethiopia: A systematic review. J Health Popul Nutr 2014;32:1-13.

2. Alharbi NS, Khaled JM, Alzaharni KE, Mothana RA, Alsaid MS, Alhoshan M, et al. Effects of Piper cubeba L. essential oil on methicillin-resistant Staphylococcus aureus: An AFM and TEM study. J Mol Recognit 2017;30:e2564; doi: 10.1002/jmr.2564.

3. Reed KB, Brewer JD, Lohse CM, Bringe KE, Pruitt $\mathrm{CN}$, Gibson LE. Increasing incidence of melanoma among young adults: An epidemiological study in Olmsted County, Minnesota. Mayo Clin Proc 2012;87:328-34.

4. Wheeler DA, Wang L. From human genome to cancer genome: The first decade. Genome Res 2013;23:1054-62.

5. Giuliano S, Cormerais Y, Dufies M, Grépin R, Colosetti P, Belaid A, et al. Resistance to sunitinib in renal clear cell carcinoma results from sequestration in lysosomes and inhibition of the autophagic flux. Autophagy 2015;11:1891-904.

This is an open access journal, and articles are distributed under the terms of the Creative Commons Attribution-Non Commercial-ShareAlike 4.0 License, which allows others to remix, tweak, and build upon the work non-commercially, as long as appropriate credit is given and the new creations are licensed under the identical terms.

\begin{tabular}{|l|l|}
\hline \multicolumn{2}{|c|}{ Access this article online } \\
\hline Quick Response Code: & Website: \\
& www.ijmpo.org \\
\cline { 2 - 2 } & DOl: \\
\hline
\end{tabular}

How to cite this article: Pandiaraja J. Incidence of malignancy in the future?. Indian J Med Paediatr Oncol 2018;39:420-1.

C 2018 Indian Journal of Medical and Paediatric Oncology | Published by Wolters Kluwer - Medknow 